International Journal of Engineering \& Technology, 7 (2.8) (2018) 295-297
International Journal of Engineering \& Technology
SPC
Website: www.sciencepubco.com/index.php/IJET
Research Paper

\title{
Advanced water level meter for alerting about floods
}

\author{
Ram. Sandeep Naidu ${ }^{1 *}$, Bodapati. Likitha Chowdary ${ }^{1}$, Jujjuri Ravi Teja $^{1}$, M.S.R. Prasad ${ }^{2}$ \\ ${ }^{1}$ Research scholar, Department of Computer Science and Engineering, Koneru Lakshmaiah Education Foundation, \\ Vaddeswaram, Guntur district, Andhra Pradesh, India \\ ${ }^{2}$ Professor, Department of Computer Science and Engineering, Koneru Lakshmaiah Education Foundation, \\ Vaddeswaram, Guntur district, Andhra Pradesh, India

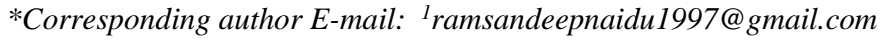

\begin{abstract}
This smaller scale show is performed on the premise of a programmable electronic printed circuit AT MEGA 2560, an electronic circuit associated with electrical protections that are situated at a particular stature, inside a water holder: when the water level ascents and achieves the resistors, differs the impedance, the data from water level sensor is transmitted by means of Wi-Fi to a portable workstation, at that point this data is additionally observed in cell phones, where clients can see the water level in waterways. At last, the smaller scale demonstrates is tried by test tests under a controlled domain and attractive outcomes are acquired. The principle point of this task is to plan a framework which will screen and control the water level in the dams and furthermore suggest the concerned expert when the water level surpasses the farthest point.
\end{abstract}

Keywords: Arduino; Compact Water Levels; Early Cautioning Framework; Flood Observatory System.

\section{Introduction}

One of the greatest natural and common calamity the whole world faces without any warning is floods. Flood hurts all the climate such as houses, crops, vehicles commercial buildings \& whatever it may. All the humans and Animals lock up flowing water. No one can disclose against water. Even if is flooding was a peculiar experience ages ago, now a day it becomes a considerable disaster. The affliction of buildings, lands, houses in floods can observed by us easily. our Govt been trying to reduce the damage such as loss of people, money and etc by investing the money on rescue team, engineers, doctors etc. To clean the roads and nature, it spends a lot money on machines. All these can be overcome with the help of efficient warning system. The ancient prediction of the floods can be very useful to deduct the loss occurred by Floods. If we can know early, then we can fight against it with the help of having things presented with us in very less time period.

Here, Project we are using microcontroller which contain all the operations in regarding ditch. A microcontroller; GSM modem; power supply; sensors used in project. Various cut off voltages having sensors are placed and affix to the Microcontroller. When the cut off voltage of stage 1 crossed by a sensor; then precautions and information sent to the Micro controller.

\section{Related Work}

In many spots, precipitation is probably going to happen unpredictably and in broadly different amounts starting with one time then onto the next. As a result, the streams which convey the surface run off fluctuate incredibly in the measure of water they convey. Subsequently, surges can be required to occur at interims as an ordinary piece of the cycle in [4].

In [5] the writer expressed that surges are the second-most across the board natural disaster on Earth. All these happens while floods / splashes arrive which dried ordinarily. Sometimes the flow of water grows rapidly. Or other way the floods slowly increases. The Floods can be occurred when the level of water; in lakes or ponds or dams can be growing than standard levels. Then excess water; comes in land and damages the surrounding areas. [6] Surges are among the most sensational structures of interaction amongst man and its condition. They are constantly related with heavy loses of life and property, hopelessness hardship sickness and now and again, starvation. There are two main reasons for surge which are common and man-made.

A few cases of normal causes are overwhelming precipitation and flooding of riverbanks which typically results to perpetual flooding. Likewise, overwhelming precipitation went with by flooding can't just aim enormous harm to structures and homes,

yet in addition kill woody and herbaceous plants in [7]. In [8] the creator articulated that huge measure of topsoil was expelled from a large area of ranch arrive. While a few sections of the scene have lost huge sums of top soil both because of sheet disintegration as rain falls on wet soils also, substantial flooding. However, the expulsion of topsoil is dependably a misfortune to rural efficiency for topsoil is that part of the dirt skyline having larger amount of natural issue and supplements which by and large has better structure. A few impacts of surge caused by characteristic causes rely upon rain fall duration, statues of water level, geology, and utilization of surge plains.

The hugest effect of flooding emerges from man-made causes like urbanization since it is having deforestation, blowing exercise adjustments, temperature rising changes; variations of the morphological; \& hydrological; condition water; [9]. Use of Flood Alarm Systems. Among every cataclysmic event on the planet, flooding constitutes the most expensive and predominant. In [10] the creator opined that there are a ton of strategies and strategies these days utilized as a part of tending to surge dangers and catastrophes. Flood Alarm Systems or Flood Warning Systems (FWS) have been presented in many countries to limit life and asset misfortunes by notice individuals in surge inclined regions to evacuate and secure their property, though some harm still happens in [11]. 
In [12] the author stated to give alert $s$ that are accelerate indications to humans. Some sirens are used in making efficient FWS. Furthermore, time to time alerts given with the help of intelligent warnings system of flood gives the indications for the floods i.e. when it occurs, how much it will be severed then everyone can able to plan for saving themselves and their business, properties etc.; Floods gives huge loose for humans, animals and everything on the earth. thought can't be stop but we can protect which we want from the water.

\section{System Architecture}

In this proposed system we are using Arduino mega microcontroller and GSM for giving information to others and we are using Ethernet. thresholds of the used sensors are determined based on the previous floods experience. number of sensors we implemented in the system. Every sensor having the different cut offs.

When the floods grow then pressure of air also varies. according to it, sensor used for e of pressure measure can detects the change and modify it to the voltage.

As the conversion voltage is analog in nature, we implement the ADC converter for understanding of microprocessor. When the floods grow then it sent the indication to the pre-registered user as a message and give a signal as a siren. The SMS is in the form of Fiji National Disaster Management Committee (DISMAC) code. Then it takes necessary steps to take precautions for the floods. Everything clearly mentioned as flow chart Figure 3.

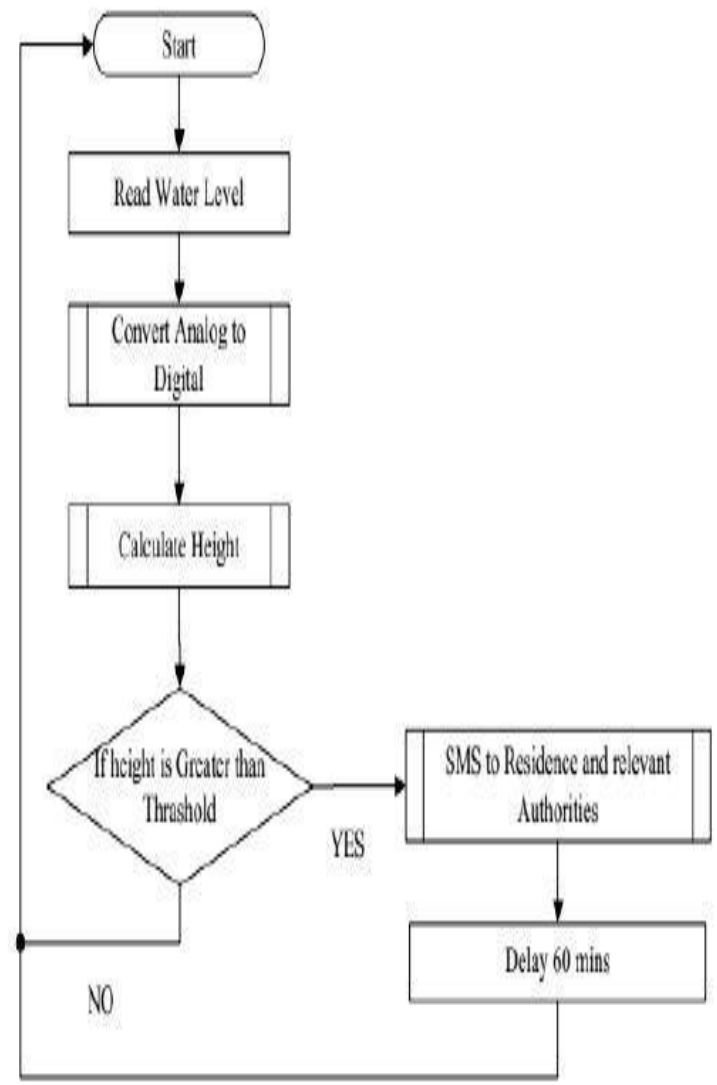

Fig. 3: Flowchart of the design of the flood level monitoring system

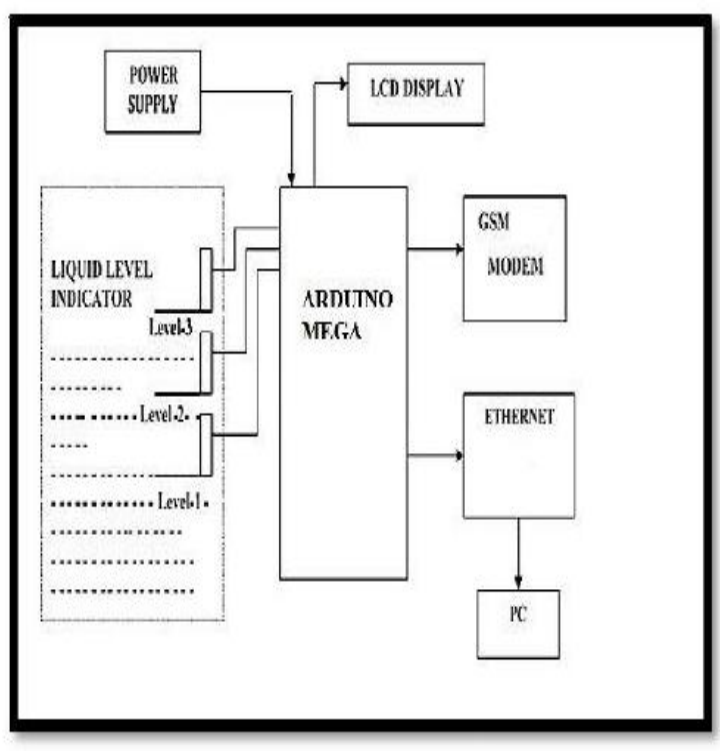

Fig. 2: Proposed System

\subsection{Arduino Mega2560}

The Arduino Mega2560 can able to contact with all variety of devices like computer; another Arduino, microcontrollers, etc. 4 UART implemented in the ATmega2560 5 volts; TTL communication which is in serial mode. board channels of the An ATmega8U2 is USB which gives virtual communications from port to the computer software (.in file must and should for Windows, Linux devices can detect automatically; Port named as COM \& The serial monitor of Arduino software offers data in the form of text sent to board.

The Board which having the receiver and transmitter light on whenever a textual data sent with the help of a chip called as mega8U2 \& a connection of a USB.

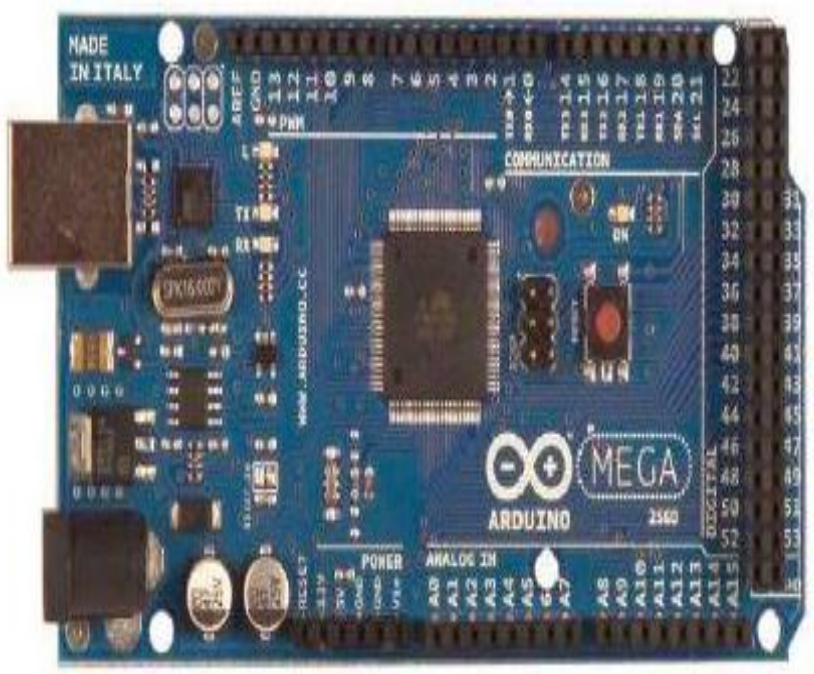

Fig. 4: Arduino Mega2560

\subsection{WL400 Water level pressure sensor}

It is high accurate and reliability. It is completely submersible sensors and cable. Its multiple ranges available from 3' to 250'. It is a one of the compensation system called dynamic temperature. Wind and rain doesn't affects this type systems.

\subsection{Liquid crystal display (LCD)}

Liquid Crystal Display (LCD) having a simple look and a viewer module. It can be very useful. M1632 LCD is the regularly used monitor in today's world. As the M1632 LCD display price is very 
less and have very less power consumption. A specially design module of LCD builds for connection with microcontroller. Figure-3 describes the LCD monitor.

\section{Conclusion}

Liquid Crystal Display (LCD) having a simple look and a viewer module. It can be very useful. M1632 LCD is the regularly used monitor in today's world. As the M1632 LCD display price is very less and have very less power consumption. A specially design module of LCD builds for connection with microcontroller. Figure-3 describes the LCD monitor.

\section{Acknowledgement}

We thank everyone who has provided insight and expertise that greatly assisted the research survey. We are also immensely grateful to the editorial board for their comments on early version of the manuscript.

\section{References}

[1] DIAD ALERT real-time weather monitoring and flood warning, DIAD Incorporated, 20September 2000, pp. 1-4.

[2] Guy Schumann, Renaud Host ache, Christian Puech, Lucien Hoffmann, Patrick Matgen,Florian Pappenberger, and Laurent Pfister, High-Resolution. 3-D Flood Information from Radar Imagery for Flood Hazard Management, IEEE Transactions on Geoscience and Remote Sensing, VOL. 45, NO. 6, June 2007, pp. 1715-1725.

[3] Gerardo Di Martino, Antonio Iodice, Daniele Riccio and Giuseppe Ruello, A Novel Approach for Disaster Monitoring: Fractal Models and Tools, IEEE Transactions on Geoscience and Remote Sensing, VOL. 45, NO. 6, June 2007, pp. 1559 - 1570.

[4] Ramsey, W. and R. Burckley. 1966. Modern Earth Science. Quezon City: KENInc.

[5] McDaniel, M., E. Sprout, D. Boudreau and A. Turgeon. 2012. Flood. <http://education.nationalgeographic.com> date accessed 17 August 2013.

[6] Mwape Y. P., 2009. An impact of floods on the socio-economic livelihoods of people: A case study of Sikaunzwe community in Kazungula, District of Zambia. University of the Free State Faculty of Natural and Agricultural Sciences Journal 1(1): 1-87.

[7] Devalsam E, I., J. E. Atu, C. Oko, I. Ekwok. 2011. Flood and its impact on farmland in Itigi, Abi Local Government Area, Cross river State,Nigeria. International Journal of Humanities and Social Sciences 1(9): 98-104.

[8] Lu, J. and K. Whitehouse. 2007. Flash flooding: Exploiting the capture effects for rapid flooding in wireless sensor networks. Department of Computer Science, University of Virgina Journal 1(1): 1-9

[9] Khalequzzaman M. D. 2009. Flood control in Bangladesh through best management practices. Department of Geology and Physics Journal 3(7): 1-13.

[10] Simonovic, S.P. 1999. Decision support systems for flood control management in theRed River Basin. Canadian Water Resources Journal 24(3): 203-223.

[11] Devalsam E, I., J. E. Atu, C. Oko, i. Ekwok. 2011. Flood and its impact on farmland in Itigi, Abi Local Government Area, Cross river State.

[12] Dr. Seetaiah Kilaru, Hari Kishore K, Sravani T, Anvesh Chowdary L, Balaji T "Review and Analysis of Promising Technologies with Respect to fifth Generation Networks", 2014 First International Conference on Networks \& Soft Computing, ISSN:978-1-4799-3486-7/14,pp.270-273, August 2014.

[13] Meka Bharadwaj, Hari Kishore "Enhanced Launch-Off-Capture Testing Using BIST Designs" Journal of Engineering and Applied Sciences, ISSN No: 1816-949X, Vol No.12, Issue No.3, page: 636-643, April 2017.

[14] P Bala Gopal, K Hari Kishore, R.R Kalyan Venkatesh, P Harinath Mandalapu "An FPGA Implementation of On Chip UART Testing with BIST Techniques", International Journal of Applied Engineering Research, ISSN 0973-4562, Volume 10, Number 14, pp. 34047-34051, August 2015.

[15] S.V.Manikanthan and K.Baskaran "Low Cost VLSI Design Implementation of Sorting Network for ACSFD in Wireless Sensor
Network", CiiT International Journal of Programmable Device Circuits and Systems,Print: ISSN 0974 - 973X \& Online: ISSN 0974 - 9624, Issue : November 2011, PDCS112011008.

[16] T. Padmapriya and V. Saminadan, "Distributed Load Balancing for Multiuser Multi-class Traffic in MIMO LTE-Advanced Networks", Research Journal of Applied Sciences, Engineering and Technology (RJASET) - Maxwell Scientific Organization, ISSN: 2040-7459; e-ISSN: 2040-7467, vol.12, no.8, pp:813-822, April 2016.

[17] S Nazeer Hussain, K Hari Kishore "Computational Optimization of Placement and Routing using Genetic Algorithm" Indian Journal of Science and Technology, ISSN No: 0974-6846, Vol No.9, Issue No.47, page: 1-4, December 2016. 